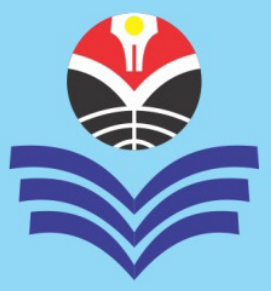

Published every March and September

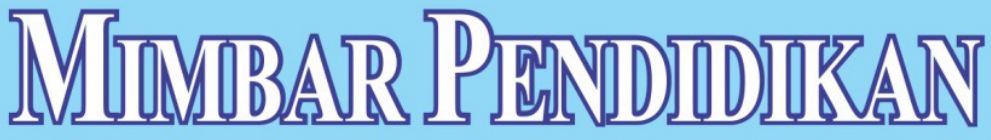

Jurnal Indonesia untuk Kajian Pendidikan

\title{
SAHRONI
}

\section{Pembelajaran Masyarakat Berbasis Masalah sebagai Strategi Meningkatkan Partisipasi Masyarakat dalam Program KOTAKU}

\begin{abstract}
ABSTRAKSI: Penelitian ini dilakukan berdasarkan permasalahan bagaimana partisipasi masyarakat dapat ditingkatkan melalui pembelajaran berbasis masalah untuk mendukung keberhasilan Program KOTAKU (Kota Tanpa Kumuh) di Kabupaten Bandung Barat, Jawa Barat, Indonesia. Tujuannya adalah untuk mendeskripsikan secara sistematis, faktual, dan akurat mengenai fakta-fakta dan sifat-sifat model pembelajaran masyarakat berbasis masalah dalam impelemenatasi program KOTAKU, sehingga dapat memberikan dampak positif terhadap peningkatan kemandirian masyarakat. Penelitian ini menggunakan pendekatan dan metode deskriptif-kualitatif. Data yang dikumpulkan menggunakan teknik studi dokumentasi, wawancara, dan observasi. Data kemudian dianalisis berdasarkan konsep pembangunan masyarakat, pembelajaran, dan pemberdayaan masyarakat. Hasil penelitian menggambarkan bahwa telah terjadi perubahan perilaku positif; perkembangan kemampuan dalam memecahkan masalah; memaknai informasi; serta berpikir reflektif dan evaluatif pada masyarakat. Penelitian ini, akhirnya, menyimpulkan bahwa secara statistik, partisipasi masyarakat dalam dimensi kontribusi mencapai $30 \%$ dalam pelaksanaannya.

KATA KUNCI: Kota Tanpa Kumuh; Partisipasi Masyarakat; Pembelajaran Berbasis Masalah.
\end{abstract}

ABSTRACT: "Problem-Based Community Learning as a Strategy to Increase Community Participation in KOTAKU Program". This research was organized based on the phenomena of how community participation can be improved through problem-based learning to support successful outcomes of KOTAKU (Kota Tanpa Kumuh or City Without Slums) Program in the Regency of Bandung Barat, West Java, Indonesia. This research was aimed to describe the facts and characteristics of problem-based community learning models in a systematic, factual, and accurate way to implement KOTAKU Program, so that it will give a positive impact on increasing community independence. This study uses a descriptive-qualitative approach and method. The data were collected by employing document analysis techniques, interviews, and observations. The data were, then, analyzed based on the concept of community development, learning, and community empowerment. The results of the study reveal that there are changing in positive behavior; the development of the ability to solve problems; interpret information; and reflective and evaluative thinking of the community. This study, finally, concluded that statistically, community participation in the contribution dimension reached $30 \%$ in its implementation.

KEY WORD: City Without Slums; Community Participation; Problem-Based Learning.

About the Author: Dr. Sahroni adalah Dosen pada Program Studi Pendidikan Sosiologi FPIPS UPI (Fakultas Pendidikan Ilmu Pengetahuan Sosial, Universitas Pendidikan Indonesia), Jalan Dr. Setiabudhi No.229 Bandung 40154, Jawa Barat, Indonesia. Untuk kepentingan akademik, Penulis bisa dihubungi dengan alamat emel: syahroni.roni@ymail.com

Suggested Citation: Sahroni. (2019). "Pembelajaran Masyarakat Berbasis Masalah sebagai Strategi Meningkatkan Partisipasi Masyarakat dalam Program KOTAKU" in MIMBAR PENDIDIKAN: Jurnal Indonesia untuk Kajian Pendidikan, Volume 4(2), September, pp.143-158. Bandung, Indonesia: UPI [Indonesia University of Education] Press, ISSN 2527-3868 (print) and 2503-457X (online).

Article Timeline: Accepted (July 10, 2019); Revised (August 24, 2019); and Published (September 30, 2019). 


\section{PENDAHULUAN}

Permasalahan kawasan pemukiman kumuh di Indonesia perlu mendapat perhatian yang sungguh-sungguh dalam penanganannya, karena kondisinya sudah memprihatinkan. Menurut data dari Kementerian PUPR (Pekerjaan Umum dan Perumahan Rakyat), sampai dengan tahun 2016, di Indonesia terdapat 35,291 hektar kawasan pemukiman kumuh; dan seluas 2,848 hektar berada di Provinsi Jawa Barat (Kementerian PUPR, 2016a dan 2016b; Ditjen Cipta Karya, 2017; dan Bathari, Limba \& Mustafa, 2018). ${ }^{1}$

Salah satu Kabupaten di Jawa Barat yang memiliki kawasan pemukiman kumuh yang luas adalah Kabupaten Bandung Barat, yaitu 121.71 hektar. Keberadaannya tersebar di 7 Desa dan 4 Kecamatan, yaitu: Kecamatan Ngamprah, Kecamatan Lembang,

Kecamatan Padalarang, dan Kecamatan Cililin. Kawasan kumuh tertinggi berada di Desa Kertamulya, Kecamatan Padalarang, dengan 26.31 hektar; diikuti Desa Ciburuy, Kecamatan Padalarang, dengan 11.71 hektar; dan Desa Bongas dengan 10.81 hektar. $^{2}$

Pemukiman kumuh adalah pemukiman yang tidak layak huni, karena ketidakteraturan bangunan, tingkat kepadatan bangunan yang tinggi, dan kualitas bangunan serta sarana dan prasarana yang tidak memenuhi syarat. Perumahan kumuh adalah perumahan yang mengalami penurunan kualitas fungsi sebagai tempat hunian (Nursyahbani \& Pigawati, 2015; Madiasworo, 2017; dan Untari, 2017).

Penanganan kawasan pemukiman kumuh bukan hanya menjadi tanggung

\footnotetext{
${ }^{1}$ Lihat juga, misalnya, "Waduh di Jabar Ada 2.848 Kawasan Pemukiman Kumuh" dalam https://finance.detik. com/.../waduh-dijabarada-2848-kawasan-pemukiman$\underline{\text { kumuh [diakses di Lembang, Jawa Barat, Indonesia: } 18}$ Maret 2019].

${ }^{2}$ Lihat "Padalarang: Antara Kemewahan dan Kawasan Paling Kumuh di Bandung Barat" dalam https://www. pikiran-rakyat.combandung-raya-padalarang-antarakemewahan-dan-kawasan-paling-kumuh-di-bandungbarat-428393 [diakses di Lembang, Jawa Barat, Indonesia: 18 Maret 2019].
}

jawab Pemerintah, melainkan tanggung jawab bersama antara Pemerintah Pusat, Pemerintah Daerah, Swasta, dan juga Masyarakat. Keterlibatan masyarakat dalam menangani kawasan pemukiman kumuh penting, karena masyarakat cenderung bersentuhan langsung dengan akar penyebab munculnya kawasan pemukiman kumuh tersebut ( $c f$ Madiasworo, 2017; Ulya, 2018; dan Lamsi, 2019).

Program KOTAKU (Kota Tanpa Kumuh) merupakan program pemerintah yang dalam pelaksanaannya melibatkan unsur Pemerintah Pusat, Pemerintah Daerah, Swasta, dan unsur Masyarakat. Program KOTAKU merupakan pengembangan dari Program NPM2K (Nasional Pemberdayaan Masyarakat Mandiri Perkotaan), yang secara khusus menangani masalah kawasan perumahan dan pemukiman kumuh. Kawasan pemukiman kumuh dimaksud yaitu pemukiman yang tidak layak huni, karena ketidakteraturan bangunan, tingkat kepadatan bangunan yang tinggi, dan kualitas bangunan serta sarana dan prasarana yang tidak memenuhi syarat (Tsanita, 2016; Fitrianingsih, 2018; dan Ulya, 2018).

Keterlibatan masyarakat sekitar dalam program ini penting, sekali lagi, karena masyarakat bersentuhan langsung dengan akar penyebab munculnya pemukiman kumuh. Itulah sebabnya, program KOTAKU dilaksanakan melalui proses pembelajaran msyarakat dan pelembagaan nilai-nilai universal kemanusiaan, atau value best develeopment; prinsip-prinsip universal kemasyarakatan, atau good gevernance; serta prinsip-prinsip pembangunan berkelanjutan, atau sustainable developmnet (Theresia, 2014; Bathari, Limba \& Mustafa, 2018; dan Nurhasanah, 2019). Permasalahannya, sekarang, adalah bagaimana partisipasi masyarakat dapat ditingkatkan melalui pembelajaran berbasis masalah?

Kajian Pustaka. Program KOTAKU (Kota Tanpa Kumuh), pada dasarnya, 
merupakan upaya membangun masyarakat yang bertumpu pada pembangunan manusia. Menurut UNDP-HDR (United Nations Development Programme - Human Development Report), pada tahun 2015, dimensi pembangunan manusia di era modern terdiri dari dua aspek. Pertama, peningkatan kemampuan manusia, yang terdiri dari peningkatan waktu hidup yang lebih lama dan sehat, peningkatan pengetahuan, serta peningkatan standar kehidupan yang layak. Kedua, penciptaan kondisi yang memungkinkan terjadinya partisipasi dalam politik dan komunitas, kondisi lingkungan dalam jangka panjang, hak dan rasa aman bagi setiap individu, serta terciptanya kesetaraan dan keadilan sosial (Kementerian PUPR, 2016a; Ditjen Cipta Karya, 2017; dan Siswoyo, 2017). ${ }^{3}$

Model pembangunan yang berpusat pada manusia (people centered) menekankan bahwa pembangunan bukan sekedar meningkatkan pertumbuhan ekonomi, pendapatan nasional atau GNP (Gross National Product), serta terpenuhinya kebutuhan dasar masyarakat, tetapi yang lebih penting lagi adalah pada upaya meningkatkan kualitas manusia agar dapat meningkatkan partisipasi secara nyata dalam berbagai aktivitas kehidupan untuk mendorong terciptanya kegiatan produktif yang bernilai tinggi (Mardikanto, 2012; Arsyad, 2017; dan Hasan \& Azis, 2018). ${ }^{4}$

Secara konseptual, pembangunan masyarakat (community development) dirancang untuk meningkatkan taraf kehidupan masyarakat secara menyeluruh dengan mendorong masyarakat untuk lebih

\footnotetext{
${ }^{3}$ Lihat juga, misalnya, "Hakikat Pembangunan Manusia: Definisi Human Development Index (HDI), Pengukuran Indeks Pembangunan Manusia, dan Permasalahan Terkini” dalam https://www.ajarekonomi. com/.../hakikat-pembangunan-manusia-h [diakses di Lembang, Jawa Barat, Indonesia: 19 Februari 2019]. ${ }^{4}$ Lihat juga, misalnya, "Pendekatan Partisipatif dalam Pemberdayaan Masyarakat" dalam http://digilib.uin-Suka. Ac.Id/8286/1/Aziz muslim [diakses di Lembang, Jawa Barat, Indonesia: 30 Maret 2019].
}

berperan aktif. Pembangunan masyarakat merupakan suatu gerakan yang meliputi berbagai program pembangunan masyarakat, baik yang dimotori oleh pemerintahan setempat maupun oleh lembaga-lembaga non-pemerintahan (Sururi, 2015; Arsyad, 2017; dan Hasan \& Azis, 2018).

Kegiatan pendataan dan pengorganisasian secara mandiri dan usaha-usaha kerjasama pihak penduduk dari komunitas yang bersangkutan merupakan upaya yang utama dari pembangunan masyarakat, yang perlu mendapat bantuan secara teknis dari pemerintah atau lembaga sukarela. Dalam pernyataan tersebut, ada suatu gerakan yang direncanakan untuk meningkatkan taraf kehidupan yang lebih baik dari segenap anggota masyarakat melalui partisipasi aktif dan adanya inisiatif dari komunitasnya (Mulyono, 2008; Arsyad, 2017; dan Hasan \& Azis, 2018).

Dengan kata lain, memberdayakan masyarakat menjadi satu kesatuan kerja dengan lembaga-lembaga pemerintahan lokal. Intinya, pembangunan masyarakat harus bertumpu dan bermuara pada community development. Dalam konteks ini, community menunjuk pada kualitas pembangunan masyarakat yang menempatkan pentingnya suatu hubungan sosial dalam masyarakat setempat. Manakala development menunjuk pada arah pembangunan masyarakat yang memiliki sifat gerakan komunitas, yakni dari masyarakat yang terencana dan berproses menuju ke arah suatu pembangunan yang menyeluruh (Mulyawan, 2016; Arsyad, 2017; dan Hasan \& Azis, 2018).

Pembangunan manusia, yang menjadi tumpuan pembangunan masyarakat, tidak bisa terlepas dari pendidikan dan pembelajaran. Adanya pembangunan masyarakat dapat memberdayakan nilainilai pemahaman, kesadaran, kepedulian, suka rela, dan partisipasi yang ditumbuhkembangkan di masyarakat; juga semakin memperjelas peran pendidikan 
dan pembelajaran dalam pembangunan masyarakat. Dari sejumlah model pembelajaran yang berkembang di Indonesia, model pembelajaran masyarakat berbasis masalah dinilai cocok untuk diterapkan dalam Program KOTAKU, yakni singkatan dari "Kota Tanpa Kumuh" (cf Irvan, 2017; Yuniani, Putri \& Rosyida, 2017; Zuharya, 2017; Apriliana, 2018; dan Kusuma, Rande \& Apriliana, 2018).

Pembelajaran berbasis masalah merupakan penggunaan berbagai macam kecerdasan yang diperlukan untuk melakukan konfrontasi terhadap tantangan dunia nyata; serta kemampuan untuk menghadapi segala sesuatu yang baru dan kompleksitas yang ada. Pendekatan pembelajaran berbasis masalah berkaitan dengan penggunaan intelegensia dari dalam diri individu yang berada di dalam sebuah kelompok orang atau lingkungan untuk memecahkan masalah yang bermakna, relevan, dan kontekstual (Ibrahim \& Nur, 2000; Rusman, 2011:230; and Arsil, 2019).

Kaitannya dengan hal tersebut, Rusman (2011) dan sarjana lainnya menjelaskan bahwa karakteristik pembelajaran berbasis masalah adalah sebagai berikut: (1) Permasalahan menjadi starting point dalam belajar; (2) Permasalahan yang diangkat adalah permasalahan yang ada di dunia nyata, yang tidak terstruktur; (3) Permasalahan membutuhkan perspektif ganda atau multiple perspective; (4)

Permasalahan menantang pengetahuan yang dimiliki oleh siswa, sikap, dan kompetensi yang kemudian membutuhkan identifikasi kebutuhan belajar dan bidang baru dalam belajar; (5) Belajar pengarahan diri menjadi hal utama; (6) Pemanfatan sumber pengetahuan yang beragam, penggunaannya, dan evaluasi sumber informasi merupakan proses yang esensial dalam PBM atau Proses Belajar-Mengajar; (7) Belajar adalah kolaboratif, komunikasi, dan kooperatif; (8) Pengembangan keterampilan inquiry dan pemecahan masalah sama pentingnya dengan pengisia pengetahuan untuk mencari solusi dari sebuah permasalahan; (9) Keterbukaan proses dalam PBM meliputi sintesis dan integrasi dari sebuah proses belajar; serta (10) PBM melibatkan evaluasi dan reviu pengalaman siswa dan proses belajar (Ibrahim \& Nur, 2000; Rusman, 2011:230; and Arsil, 2019).

Karakteristik pembelajaran berbasis masalah erat kaitannya dengan belajar melalui tukar belajar yang disejajarkan dengan belajar mengarahkan diri, yaitu seorang yang mempelajari materi atau keahlian tertentu bersama orang lain, yang mau menjadi pembelajar atau sumber belajar. Manakala partisipasi masyarakat merupakan wujud partisipasi yang diberikan oleh masyarakat terhadap program. Bentukbentuk partisipasi masyarakat meliputi partisipasi dalam bentuk buah pikiran atau keahlian, pembiayaan atau uang, tenaga atau fisik, dan material (Rusman, 2011; Rohimat, Rahmawati \& Seran, 2015; dan Nurzen et al., 2019).

Partisipasi masyarakat dalam proses penyelenggaraan Program KOTAKU (Kota Tanpa Kumuh) merupakan keikutsertaan masyarakat dalam kegiatan yang dilaksanakan, yang meliputi: partisipasi pada tahap perencanaan, tahap pelaksanaan, tahap evaluasi atau monitoring, dan tahap pemanfaatan hasil (Rohimat, Rahmawati \& Seran, 2015; Christianingrum \& Djumiarti, 2017; dan Hadi \& Umilia, 2018).

\section{METODE}

Penelitian ini menggunakan metode deskriptif kualitatif untuk melihat lebih dalam bentuk partisipasi, tingkat partisipasi, dan faktor-faktor yang mempengaruhi partisipasi hasil pembelajaran berbasis masalah. Metode kualitatif sering digunakan untuk melihat lebih dalam suatu fenomena sosial, termasuk di dalamnya kajian terhadap ilmu pendidikan, manajemen dan administrasi bisnis, kebijakan publik, pembangunan, atau pun hukum. Temuan- 
temuan kualitatif diarahkan untuk menghasilkan perbaikan-perbaikan mutu kerja dan bermanfaat untuk kepentingan akademis (Moeloeng, 1993; Gunawan, 2013; dan Indrawan \& Yaniawati, 2017:68).

Pengumpulan data menggunakan teknik studi literatur, wawancara, dan observasi lapangan, yang melibatkan tujuh lembaga keswadayaan masyarakat di Kabupaten Bandung Barat, Jawa Barat, Indonesia. Wawancara dilakukan untuk mendalami informasi yang diperoleh melalui studi literatur dan observasi lapangan, serta difokuskan kepada pendampingan yang dilakukan oleh fasilitator terhadap lembaga keswadayaan masyarakat dan kelompok swadaya masyarakat. Data dianalisis berdasarkan konsep pembelajaran masyarakat berbasis masalah, konsep pemberdayaan, dan konsep KOTAKU (Kota Tanpa Kumuh), sehingga dapat dirumuskan kesimpulan (Sugiyono, 2009; Gunawan, 2013; dan Indrawan \& Yaniawati, 2017).

\section{HASIL DAN PEMBAHASAN}

Sasaran dan Prioritas Program. Sasaran Program KOTAKU (Kota Tanpa Kumuh), pada dasarnya, adalah daerah-daerah yang memenuhi indikator kumuh. Ada tujuh indikator kawasan pemukiman kumuh, yaitu: kondisi bangunan (keteraturan, kepadatan, dan kondisi fisik); jalan lingkungan; drainase lingkungan; air limbah; air bersih/air minum; pengelolaan persampahan; dan pengamanan bahaya kebakaran. Namun, sesuai dengan Surat Keputusan Bupati Bandung Barat, Nomor 663/Kep/447/Disperkim/2017, ditetapkan bahwa kawasan perumahan kumuh dan pemukiman kumuh perkotaan di Kabupaten Bandung Barat, yaitu:

Kecamatan Padalarang, yang meliputi Desa Padalarang, Ciburuy, dan Kertamulya; Kecamatan Ngamprah, yang meliputi Desa Mekasari dan Cimareme; serta Kecamatan Lembang, yang meliputi Desa Lembang dan Gudangkahuripan (Kurnia, Sjamsudin \&
Rozikin, 2010; Kementerian PUPR, 2016a dan 2016b; dan Ditjen Cipta Karya, 2017). ${ }^{5}$

Setiap Desa mempunyai masalah pemukiman kumuh dan prioritas program yang berbeda-beda, ${ }^{6}$ seperti terlihat pada tabel 1.

Data pada tabel 1 memperlihatkan bahwa penyelesaian masalah sampah menjadi program prioritas. Berikutnya adalah masalah jalan lingkungan; drainase lingkungan; air bersih; dan air limbah. Tidak ada program pengamanan bahaya kebakaran dan keteraturan/kepadatan bangunan.

Berkenaan dengan anggaran biaya, kegiatan didanai dari BDI (Bantuan Dana Investasi) dan swadaya masyarakat, dengan perbandingan $70 \%$ dari BDI dan 30\% dari swadaya masyarakat (cf Rukminto, 2003; Madiasworo, 2017; Apriliana, 2018; dan wawancara dengan Responden A, 3/7/2018).

Swadaya masyarakat, yang sering disejajarkan dengan partisipasi masyarakat, adalah keterlibatan langsung masyarakat dalam penyelesaian masalah pemukiman kumuh, yang meliputi kontribusi, pengorganisasian, dan pemberdayaan masyarakat. Indikator kontribusi masyarakat meliputi pemikiran, dana, tenaga, dan sarana. Indikator pengorganisasian masyarakat meliputi model pengorganisasian, struktur pengorganisasian, unsur-unsur pengorganisasian, dan fungsi pengorganisasian. Serta indikator pemberdayaan masyarakat meliputi aksi masyarakat, motivasi masyarakat, dan tanggung jawab ( $c f$ Rohimat, Rahmawati \& Seran, 2015; Tsanita, 2016; Ulya, 2018; dan wawancara dengan Responden A, 3/7/2018).

Dilihat dari dimensi kontribusi dan

\footnotetext{
${ }^{5}$ Lihat juga, misalnya, "Surat Keputusan Bupati Bandung Barat, Nomor 663/Kep.447/Disperkim/2017 tentang Penetapan Wilayah Penerima Program Kota Tanpa Kumuh". Arsip Tidak Diterbitkan. Tersedia dan dimiliki oleh Penulis.

${ }^{6}$ Lihat, misalnya, "Laporan Pelaksanaan Program KOTAKU KBB (Kota Tanpa Kumuh Kabupaten Bandung Barat) Tahun 2018". Naskah Tidak Diterbitkan. Tersedia dan dimiliki oleh Penulis.
} 
Tabel 1:

Data Pelaksanaan Program KOTAKU Kabupaten Bandung Barat Tahun 2018

\begin{tabular}{|c|c|c|c|c|}
\hline Desa & KSM & Progam Kegiatan & Volume & Satuan \\
\hline Padalarang & Garuda 3 & Jalan Lapen (Lapisan Penetrasi) & 133 & $\mathrm{M}$ \\
\hline Padalarang & Garuda 4 & Drainase Lingkungan & 140 & M \\
\hline Padalarang & Walet 2 & Gerobak/Motor Sampah & 2 & Unit \\
\hline Padalarang & Walet 1 & Sumur Bor & 1 & Unit \\
\hline Padalarang & Walet 4 & Jalan Lapen (Lapisan Penetrasi) & 93 & M \\
\hline Padalarang & Rajawali 3 & Sumur Bor & 1 & Unit \\
\hline Padalarang & Rajawali 4 & Drainase Lingkungan & 500 & M \\
\hline Padalarang & Rajawali 1 & Gerobak/Motor Sampah & 2 & Unit \\
\hline Padalarang & Gagak 1 & Gerobak/Motor Sampah & 2 & Unit \\
\hline Padalarang & Gagak 2 & Sumur Bor & 1 & Unit \\
\hline Padalarang & Gagak 3 & Sumur Bor & 1 & Unit \\
\hline Padalarang & Gagak 4 & Septictank Komunal & 2 & Unit \\
\hline Ciburuy & CIP 1 & Drainase Lingkungan & 137 & M \\
\hline Ciburuy & Senada 1 & Drainase Lingkungan & 123 & M \\
\hline Ciburuy & Senada 2 & Tempat Pembuangan Sampah Sementara & 1 & Unit \\
\hline Ciburuy & Mawar 1 & Drainase Lingkungan & 100 & M \\
\hline Ciburuy & Mawar 2 & Drainase Lingkungan & 100 & M \\
\hline Ciburuy & Mawar 3 & Drainase Lingkungan & 63 & M \\
\hline Ciburuy & Sidang Barokah & Drainase Lingkungan & 200 & M \\
\hline Ciburuy & Ciburuy Berseka 1 & Gerobak/Motor Sampah & 2 & Unit \\
\hline Ciburuy & Ciburuy Berseka 2 & Gerobak/Motor Sampah & 2 & Unit \\
\hline Ciburuy & Ciburuy Berseka 3 & Gerobak/Motor Sampah & 2 & Unit \\
\hline Ciburuy & CIP 2 & Drainase Lingkungan & 100 & M \\
\hline Kertamulya & POS Kulon 1 & Perpipaan & 568 & M \\
\hline Kertamulya & POS Kulon 3B & Gerobak/Motor Sampah & 1 & Unit \\
\hline Kertamulya & POS Kulon 3B & Jalan Lapen (Lapisan Penetrasi) & 293 & M \\
\hline Kertamulya & POS Kulon 4 & Gerobak/Motor Sampah & 1 & Unit \\
\hline Kertamulya & POS Wetan 11A & Jalan Lapen (Lapisan Penetrasi) & 361 & M \\
\hline Kertamulya & POS Wetan 11B & Sumur Bor & 1 & Unit \\
\hline Kertamulya & POS Wetan 11C & Gerobak/Motor Sampah & 1 & Unit \\
\hline Kertamulya & POS Wetan 12 & Gerobak/Motor Sampah & 1 & Unit \\
\hline Kertamulya & POS Wetan 13A & Jalan Lapen (Lapisan Penetrasi) & 532 & M \\
\hline Kertamulya & POS Wetan 13B & Drainase Lingkungan & 180 & M \\
\hline Kertamulya & Cikurai 14A & Septictank Komunal & 3 & Unit \\
\hline Kertamulya & Cikurai 14C & Drainase Lingkungan & 50 & M \\
\hline Kertamulya & Cikurai 14C & Jalan Lapen (Lapisan Penetrasi) & 114 & M \\
\hline Kertamulya & Cikurai 14B & Gerobak/Motor Sampah & 1 & Unit \\
\hline Kertamulya & POS Kidul 18 & Drainase Lingkungan & 350 & M \\
\hline Kertamulya & POS Kidul 19 & Jalan Lapen (Lapisan Penetrasi) & 173 & M \\
\hline Mekarsari & Mandiri & Jalan Paving Block & 128 & Meter \\
\hline Mekarsari & Bina Warga & Jalan Paving Block & 148 & Meter \\
\hline Mekarsari & Mekar Laksana & Jalan Paving Block & 89 & Meter \\
\hline Mekarsari & Berseka & Gerobak/Motor Sampah & 1 & Unit \\
\hline Mekarsari & Berseka 2 & Sumur Bor & 1 & Unit \\
\hline Cimareme & Tegar & Jalan Paving Block & 235 & Meter \\
\hline Cimareme & Kuat & Drainase Lingkungan & 235 & Meter \\
\hline Cimareme & Kokoh & Gerobak/Motor Sampah & 1 & Unit \\
\hline Cimareme & Kokoh & Sumur Bor & 1 & Unit \\
\hline Lembang & Bina Usaha 2 & Jalan Aspal Hotmix & 54 & Meter \\
\hline
\end{tabular}




\begin{tabular}{lllcc}
\hline Desa & KSM & Progam Kegiatan & Volume & Satuan \\
\hline Lembang & Bina Usaha 3 & Drainase Lingkungan & 200 & Meter \\
Lembang & Bina Usaha 1 & Jalan Aspal Hotmix & 200 & Meter \\
Lembang & Bina Usaha 2 & Drainase Lingkungan & 34 & Meter \\
Lembang & Bina Usaha 3 & Jalan Beton & 106 & Meter \\
Lembang & Patrio & Jalan Aspal Hotmix & 152 & Meter \\
Lembang & Patrio & Jalan Aspal Hotmix & 91 & Meter \\
Lembang & Boscha Sejahtera & Perpipaan & 420 & Meter \\
Lembang & Boscha Sejahtera & Jalan Aspal Hotmix & 200 & Meter \\
Lembang & Seruni1 & Septictank Komunal & 3 & Unit \\
Lembang & Seruni 2 & Jalan Aspal Hotmix & 230 & Meter \\
Lembang & Seruni 3 & Drainase Lingkungan & 72 & Meter \\
Lembang & Bintang Kejora 1 & Gerobak/Motor Sampah & 1 & Unit \\
Lembang & Bintang Kejora 2 & Gerobak/Motor Sampah & 1 & Unit \\
Lembang & Bintang Kejora 3 & Gerobak/Motor Sampah & 1 & Unit \\
Gudangkahuripan & Ampar Jagat 2 & Gerobak/Motor Sampah & 1 & Unit \\
Gudangkahuripan & Ampar Jagat 3 & Gerobak/Motor Sampah & 1 & Unit \\
Gudangkahuripan & Lembah Asri 2 & Jalan Paving Block & 40 & Meter \\
Gudangkahuripan & Lembah Asri 2 & Saluran Pembuangan Limbah Rumah & 350 & Meter \\
& & Tangga & & Tempat Pembuangan Sampah Sementara \\
Gudangkahuripan & Lembah Asri 2 & Jalan Aspal Hotmix & 1 & Unit \\
Gudangkahuripan & Sasakala & Saluran Pembuangan Limbah Rumah & 197 & Meter \\
Gudangkahuripan & Sasakala & Tangga & 1 & Meter \\
Gudangkahuripan & Sasakala & MCK Mandi + Cuci + Kakus & Unit \\
\hline
\end{tabular}

swadaya, partisipasi masyarakat dalam menangani masalah pemukiman kumuh di Kabupaten Bandung Barat termasuk bagus, yakni bisa menghemat anggaran sebesar 30\% (cf Rukminto, 2003; Madiasworo, 2017; Apriliana, 2018; dan wawancara dengan Responden A, 3/7/2018).

Partisipasi Masyarakat. Bentuk partisipasi masyarakat dalam pengelolaan Program KOTAKU (Kota Tanpa Kumuh) dibagi menjadi tiga, yaitu: dimensi kontribusi, dimensi pengorganisasian, dan dimensi pemberdayanaan masyarakat. Ketiga dimensi tersebut diperlihatkan pada setiap tahapan kegiatan, yang meliputi tahap persiapan, pelaksanaan, tahap evaluasi, dan tindak lanjut. Secara rinci, tahapan pemberdayaan masyarakat meliputi rembug kesiapan warga, sosialisasi program, pendataan relawan, refleksi, pemetaan swadaya, penguatan atau pembentukan badan keswadayaan masyarakat, penyusunan perencanaan, pelaksanaan kegiatan, serta evaluasi dan tindak lanjut
(Sahroni, 2013; Irvan, 2017; Apriliana, 2018; dan wawancara dengan Responden B, 3/7/2018).

Partisipasi masyarakat pada setiap tahapan kegiatan terlihat dari kegiatan berikut: (1) Tahap Persiapan; (2) Tahap Pelaksanaan; serta (3) Tahap Evaluasi dan Tindak Lanjut. Masing-masing tahap dapat dijelaskan, sebagai berikut:

Pertama, Tahap Persiapan. Tahap ini meliputi kegiatan-kegiatan, seperti: rembug kesiapan warga untuk menyatakan kesiapan menerima atau menolak dilaksanakannya Program KOTAKU (Kota Tanpa Kumuh). Kehadiran warga dalam kegiatan ini diperlukan agar keputusan yang diambil merepresentasikan suara masyarakat ( $c f$ Sahroni, 2013; Kementerian PUPR, 2016b; Yuniani, Putri \& Rosyida, 2017; dan wawancara dengan Responden B, 3/7/2018).

Sosialisasi awal mengenai substansi Program KOTAKU untuk menumbuhkan pemahaman dan kesadaran kritis tentang prinsip dan nilai Program KOTAKU kepada 
masyarakat. Partisipasi aktif masyarakat dalam sosialisasi ini menjadi harapan semua pihak (Sururi, 2015; Kementerian PUPR, 2016b; Ditjen Cipta Karya, 2017; dan wawancara dengan Responden C, 10/7/2018).

Pendataan relawan untuk menghasilkan daftar relawan setempat, sebagai penggerak dan pelaksana setiap tahapan kegiatan dilakukan oleh masyarakat. Masyarakat paham arti penting kerelawanan dalam mendorong tumbuh-kembangnya solidaritas sosial, kepedulian bersama, kemandirian, serta keswadayaan untuk menanggulangi persoalan pemukiman kumuh di wilayahnya (Kementerian PUPR, 2016b; Ditjen Cipta Karya, 2017; Apriliana, 2018; dan wawancara dengan Responden D, 10/7/2018).

Refleksi kawasan pemukiman kumuh untuk menumbuhkan kesadaran kritis masyarakat bahwa akar persoalan pemukiman kumuh adalah lunturnya nilainilai luhur kemanusiaan untuk berbuat kebajikan dan peduli terhadap sesama (Kementerian PUPR, 2016b; Ditjen Cipta Karya, 2017; Madiasworo, 2017; dan wawancara dengan Responden E, 17/7/2018).

Pemetaan swadaya untuk menumbuhkan kesadaran masyarakat tentang kondisi realitas saat ini dan membangun kesepakatan tentang kondisi ideal yang diinginkan, sehingga terkumpul data kawasan pemukiman kumuh (Kementerian PUPR, 2016b; Ditjen Cipta Karya, 2017; Nurhasanah, 2019; dan wawancara dengan Responden F, 17/7/2018).

Penguatan atau pembentukan Badan Keswadayaan Masyarakat dan Kelompok Swadaya Masyarakat. Pembentukan kelembagaan dilakukan apabila di suatu daerah belum terbentuk lembaga keswadayaan masyarakat atau kelompok swadaya masyarakat. Sedangkan penguatan kelembagaan dilakukan pada daerah yang sudah terbentuk lembaga keswadayaan masyarakat atau kelompok swadaya masyarakat, tapi aktivitasnya kurang. Melalui kegiatan ini tumbuh kesadaran kritis dan kesepakatan bersama untuk memanfaatkan kelembagaan masyarakat yang ada, atau membentuk yang baru (cf Kurnia, Sjamsudin \& Rozikin, 2010; Rohimat, Rahmawati \& Seran, 2015; Ditjen Cipta Karya, 2017; dan wawancara dengan Responden G, 24/7/2018).

Penyusunan perencanaan kegiatan penyelesaian kawasan pemukiman kumuh oleh masyarakat setempat. Dalam upaya menampung aspirasi warga sebagai bahan penyusunan rencana tahunan, dilakukan rembug warga tahunan yang melibatkan unsur pemerintahan Desa, pengurus RT/ RW (Rukun Tetangga/Rukun Warga), tokoh masyarakat, relawan khusus, dan pengurus BKM (Badan Keswadayaan Masyarakat) dan KSM (Kelompok Swadaya Masyarakat). Dalam rembug warga tahunan itu disepakati kegiatan-kegiatan yang akan dilaksanakan satu tahun ke depan, tempat dilaksanakannya kegiatan, waktu pelaksanaan kegiatan, dan pengelola kegiatan (Kurnia, Sjamsudin \& Rozikin, 2010; Kementerian PUPR, 2016b; Ditjen Cipta Karya, 2017; dan wawancara dengan Responden H, 24/7/2018).

Kedua, Tahap Pelaksanaan. Partisipasi aktif masyarakat pada tahap pelaksanaan, pada umumnya, dalam bentuk kontribusi pemikiran, barang, uang, peralatan, dan tenaga. Bergotong-royong di bawah koordinasi pengurus kelompok swadaya masyarakat. Masyarakat juga terlibat dalam melakukan pengawasan dan pengendalian agar ada kesesuaian antara apa yang dikerjakan dengan yang direncanakan, sebagaimana tertuang dalam perencanaan kegiatan (Kementerian PUPR, 2016b; Ditjen Cipta Karya, 2017; wawancara dengan Responden A, 3/7/2018; wawancara dengan Responden C, 10/7/2018; wawancara dengan Responden E, 17/7/2018; dan wawancara dengan Responden G, 24/7/2018). 


\section{Ketiga, Tahap Evaluasi dan Tindak} Lanjut. Evaluasi dan tindak lanjut program dilaksanakan dalam bentuk rembug warga tahunan. Pada forum ini, partisipasi masyarakat diperlukan untuk bersamasama mengevaluasi keterlaksanaan dan ketercapaian tujuan program kegiatan. Mereviu apa yang terjadi dalam rangkaian proses kegiatan untuk bahan pertimbangan pengambilan keputusan. Salah satu bentuk tindak lanjut dari kegiatan rembug warga tahunan adalah pembentukan tim pemelihara hasil kegiatan, yang anggotanya dipilih dari masyarakat setempat. Artinya, dalam memelihara hasil kegiatan memerlukan partisipasi masyarakat (Kementerian PUPR, 2016b; Ditjen Cipta Karya, 2017; wawancara dengan Responden B, 3/7/2018; wawancara dengan Responden D, 10/7/2018; wawancara dengan Responden F, 17/7/2018; dan wawancara dengan Responden H, 24/7/2018).

\section{Tingkat Partisipasi Masyarakat.}

Tingkat partisipasi diukur dari berapa besar anggota masyarakat dalam tiap tahapan kegitan dan dimensi partisipasi, serta apa yang dominan dilakukan pada masingmasing tahapan kegiatan. Mencermati deskripsi tentang bentuk partisipasi di atas, jelas memperlihatkan bahwa partisipasi dimensi kontribusi mendominasi di setiap tahapan kegiatan. Pada tahap persiapan, lebih dominan kontribusi pemikiran; pada tahap pelaksanaan, lebih dominan kontribusi uang, barang, dan tenaga; serta pada tahap evaluasi dan tindak lanjut, lebih dominan kontribusi tenaga, barang, dan uang ( $c f$ Ulya, 2018; Nurhasanah, 2019; wawancara dengan Responden A, 3/7/2018; wawancara dengan Responden C, 10/7/2018; wawancara dengan Responden E, 17/7/2018; dan wawancara dengan Responden G, 24/7/2018).

Dimensi pengorganisasian terlihat pada semua tahapan kegiatan, demikian juga dengan dimensi pemberdayaan. Intinya adalah bahwa ketiga dimensi partisipasi ada dalam pelaksanaan program kegiatan. Namun, apabila diurutkan berdasarkan tingkat partisipasi masyarakat, maka: pertama adalah dimensi kontribusi, kedua adalah dimensi pemberdayaan, dan ketiga adalah dimensi pengorganisasian (wawancara dengan Responden B, 3/7/2018; wawancara dengan Responden D, 10/7/2018; wawancara dengan Responden F, 17/7/2018; dan wawancara dengan Responden H, 24/7/2018).

\section{Proses Pembelajaran Masyarakat}

Berbasis Masalah. Pembelajaran berbasis masalah, yang dilakukan oleh masyarakat penerima Program KOTAKU (Kota Tanpa Kumuh), didasarkan oleh teori konstruktivisme yang memandang bahwa pemahaman diperoleh dari interaksi dengan skenario permasalahan dan lingkungan belajar. Pergulatan dengan masalah dan proses inkuiri masalah menciptakan disonansi kognitif yang menstimulasi belajar. Pengetahuan terjadi melalui proses kolaborasi, negosiasi sosial, dan evaluasi terhadap keberadaan sebuah sudut pandang (cf Irvan, 2017; Yuniani, Putri \& Rosyida, 2017; Zuharya, 2017; Apriliana, 2018; dan Kusuma, Rande \& Apriliana, 2018).

Dilihat dari materi yang dipelajari, pembelajaran masyarakat berbasis masalah ini memusatkan pembelajaran pada masalah-masalah yang berkaitan dengan pemukiman kumuh, yaitu: masalah kondisi bangunan (keteraturan, kepadatan, dan kondisi fisik); masalah jalan lingkungan; drainase lingkungan; air limbah; air bersih/ air minum; pengelolaan persampahan; dan pengamanan bahaya kebakaran. Masyarakat mempelajari hal tersebut melalui kegiatankegiatan yang ada dalam proses bisnis Program KOTAKU. Mulai dari rembug kesiapan warga, sosialisasi substansi, pendataan relawan, refleksi kawasan kumuh, pemetaan swadaya, penguatan kelembagaan, penyusunan perencanaan kegiatan, melaksanakan kegiatan, hingga memanfaatkan dan memelihara hasil 
kegiatan (Kementerian PUPR, 2016b; Ditjen Cipta Karya, 2017; dan Bathari, Limba \& Mustafa, 2018).

Pembelajaran dilaksanakan secara terpadu dalam proses bisnis program kegiatan, yang dimulai sejak sosialisasi awal mengenai substansi Program KOTAKU kepada masyarakat. Saat itu mulai ditumbuhkan pemahaman tentang prinsip dan nilai Program KOTAKU sebagai pondasi yang kokoh dalam upaya menanggulangi kawasan pemukiman kumuh secara mandiri, efektif, dan berkelanjutan. Masyarakat belajar arti penting gotong-royong dan partisipasi masyarakat dalam penyelesaian masalah pemukiman kumuh. Semua itu terangkum dalam konsep dasar Program KOTAKU, yang disosialisasikan oleh fasilitator (Kementerian PUPR, 2016b; Ditjen Cipta Karya, 2017; dan Nurhasanah, 2019).

Belajar memahami tujuan Program KOTAKU meliputi: (1) Meningkatkan partisipasi seluruh masyarakat, kapasitas kelembagaan masyarakat yang mengakar, representatif, dan akuntabel; (2) Menyinergikan masyarakat, pemerintah daerah, asosiasi, dan swasta dalam menangani masalah sosial di masyarakat;

(3) Mengefektifkan upaya-upaya penanggulangan kawasan pemukiman kumuh; (4) Meningkatkan keberdayaan dan kemandirian masyarakat dan kelompok setempat dalam menanggulangi kawasan pemukiman kumuh; serta (5) Meningkatkan modal sosial masyarakat, sesuai dengan potensi sosial dan budaya yang dimiliki (Kementerian PUPR, 2016b; Ditjen Cipta Karya, 2017; dan Zuharya, 2017).

Masyarakat belajar peduli terhadap lingkungan dengan cara mengamati masalah kumuh di wilayahnya, seberapa parah masalah tersebut, dan bagaimana kepedulian masyarakat sekitar terhadap penyelesaian masalah selama ini. Pembelajaran ini terjadi saat mereka mengidentifikasi masalah kumuh yang ada di wilayahnya dan dikoordinasikan oleh kelompok swadaya masyarakat. Hasil identifikasi tersebut berupa data pemukiman kumuh, sesuai indikator kumuh yang telah ditetapkan. Setiap Desa memiliki data kumuh masingmasing; namun secara umum, pemukiman kumuh di Kabupaten Bandung Barat, Jawa Barat, Indonesia adalah masalah sampah, jalan lingkungan, drainase lingkungan, air bersih, dan air limbah (Kementerian PUPR, 2016b; Ditjen Cipta Karya, 2017; wawancara dengan Responden A, 3/7/2018; wawancara dengan Responden C, 10/7/2018; wawancara dengan Responden E, 17/7/2018; dan wawancara dengan Responden G, 24/7/2018).

Masyarakat belajar kesadaran kritis pada tahap kegiatan refleksi kawasan pemukiman kumuh. Pada tahap ini, masyarakat belajar memahami kemungkinan penyebab munculnya masalah tersebut, bagaimana tingkat kemendesakan masalah-masalah itu untuk diselesaikan, dan menemukan solusinya. Masyarakat belajar memahami bahwa akar persoalan pemukiman kumuh adalah lunturnya nilai-nilai luhur kemanusiaan untuk berbuat kebajikan dan peduli terhadap sesama. Penyelesaiannya adalah merupakan tanggung jawab bersama, bukan hanya tanggung jawab penghuni pemukiman kumuh (cf Zuharya, 2017; Lamsi, 2019; dan Nurhasanah, 2019).

Upaya penyelesaian dimulai dari diri sendiri, melalui perubahan mental dan perilaku individu yang pada gilirannya menjadi perilaku kolektif. Tergalinya aspirasi dan harapan mengenai penyelesaian masalah pemukiman kumuh dengan mengindetifikasi penyebab pemukiman kumuh, kriteria kumuh, dan upaya penanggulangannya. Lahirnya kesepakatan langkah-langkah penyelesaian masalah pemukiman kumuh, secara kolektif, melalui penumbuh-kembangan nilai dan prinsip yang diusung oleh Program KOTAKU (Kementerian PUPR, 2016b; Ditjen Cipta Karya, 2017; 
wawancara dengan Responden B, 3/7/2018; wawancara dengan Responden D, 10/7/2018; wawancara dengan Responden F, 17/7/2018; dan wawancara dengan Responden H, 24/7/2018).

Tumbuhnya kepedulian dan kesatuan semua lapisan warga masyarakat, baik warga miskin maupun warga tidak miskin, untuk bersama-sama menyelesaikan persoalan pemukiman kumuh. Solusi yang dipilih, selanjutnya, dijabarkan dan dituangkan dalam rencana kegiatan yang diusulkan pendanaannya dari Program KOTAKU. Dalam hal ini, masyarakat belajar membuat rencana kegiatan yang baik, yaitu membuat perencanaan berdasarkan hasil analisis kebutuhan (Kementerian PUPR, 2016b; Ditjen Cipta Karya, 2017; wawancara dengan Responden A, 3/7/2018; wawancara dengan Responden C, 10/7/2018; wawancara dengan Responden E, 17/7/2018; dan wawancara dengan Responden G, 24/7/2018).

Masyarakat belajar bentuk-bentuk partisipasi, yang bisa dipilih untuk membantu menyelesaikan masalah kawasan kumuh di daerahnya melalui ketentuan bahwa sekecil apapun sumbangan masyarakat harus dicatat, dikonversi ke dalam nilai uang sehingga menjadi nilai swadaya masyarakat. Pembelajaran ini terjadi pada saat pelaksanaan kegiatan, dimana panitia mencatat partisipasi masyarakat, baik berupa uang, barang, makanan, dan minuman, maupun tenaga. Semuanya dicatat, dihitung, dan dilaporkan sehingga menjadi bagian dari keseluruhan realisasi biaya kegiatan (Kementerian PUPR, 2016b; Ditjen Cipta Karya, 2017; wawancara dengan Responden B, 3/7/2018; wawancara dengan Responden D, 10/7/2018; wawancara dengan Responden F, 17/7/2018; dan wawancara dengan Responden H, 24/7/2018).

Masyarakat juga belajar bagaimana mensyukuri atas diselesaikannya masalah pemukiman kumuh di wilayahnya. Bentuk syukur yang diajarkan melalui dua cara, yaitu: memanfaatkan dan memelihara hasil kegiatan. Sesuai dengan konsep dasarnya bahwa hasil kegiatan Program KOTAKU harus dapat dimanfaatkan dengan sebaik-baiknya untuk kepentingan umum. Agar dapat dimanfaatkan untuk kepentingan umum, dalam waktu lama tentunya, perlu dipelihara dengan baik, teratur, dan berkelanjutan; serta yang paling bertanggung jawab memelihara hasil kegiatan tersebut adalah masyarakat setempat (Kementerian PUPR, 2016b; Ditjen Cipta Karya, 2017; wawancara dengan Responden A, 3/7/2018; wawancara dengan Responden C, 10/7/2018; wawancara dengan Responden E, 17/7/2018; dan wawancara dengan Responden G, 24/7/2018).

Semuanya mengajarkan masyarakat untuk menyelesaikan masalah pemukiman kumuh secara sistematis, terencana, dan terintegrasi dengan memberdayakan enam modal utama sebagai asset masyarakat. Proses pembelajaran itu terjadi pada kegiatan menyusun rencana kegiatan, melaksanakan kegiatan, dan mengevaluasi kegiatan, dimana masyarakat memegang peranan penting dalam kegiatan tersebut. Program KOTAKU, dengan demikian, sering disebut kegiatan dari, oleh, dan untuk masyarakat (Rohimat, Rahmawati \& Seran, 2015; Apriliana, 2018; Kusuma, Rande \& Apriliana, 2018; wawancara dengan Responden A, 3/7/2018).

Dilihat dari alur proses pembelajaran di atas dapat disejajarkan dengan proses pembelajaran berbasis masalah. Aktivitas sosialisasi, rembug warga, identifikasi masalah, analisis masalah, refleksi, pemetaan swadaya, dan solusi dalam proses bisnis Program KOTAKU merupakan alur proses pembelajaran berbasis masalah. Dalam konteks ini, Rusman (2011), dan sarjana lainnya, mengemukakan bahwa alur proses pembelajaran berbasis masalah adalah menentukan masalah; analisis 
masalah dan isu belajar; pertemuan dan pelaporan; penyajian solusi dan refleksi; kesimpulan; integrasi; dan evaluasi (Ibrahim \& Nur, 2000; Rusman, 2011:223; Ditjen Cipta Karya, 2017; Apriliana, 2018; dan Arsil, 2019).

Tujuan pembelajaran berbasis masalah dalam Program KOTAKU adalah terjadinya perubahan perilaku masyarakat, mengembangkan keterampilan dalam memecahkan masalah, memaknai informasi, serta berpikir reflektif dan evaluatif guna meningkatkan partisipasi masyarakat dalam menyelesaikan masalah pemukiman kumuh. Perubahan perilaku warga masyarakat diperlihatkan menjadi lebih disiplin dalam membuang sampah, karena di daerahnya tersedia sarana, prasarana, dan pengelola sampah; serta tidak membuang limbah keluarga sembarangan, karena tersedia septikteng komunal dan menggunakan air bersih seperlunya untuk keperluan rumah tangga (Kementerian PUPR, 2016b; Ditjen Cipta Karya, 2017; wawancara dengan Responden A, 3/7/2018; wawancara dengan Responden C, 10/7/2018; wawancara dengan Responden E, 17/7/2018; dan wawancara dengan Responden $\mathrm{G}$, 24/7/2018).

Peningkatan pengetahuan dan pemahaman arti penting gotongroyong dalam menyelesaikan masalah pemukiman kumuh diperlihatkan oleh besarnya kontribusi yang diberikan. Peningkatan pengalaman dan keterampilan menyelesaikan masalah pemukiman kumuh diperlihatkan oleh kemampuan memilih solusi penyelesaian masalah pemukiman kumuh. Semunya itu merupakan faktorfaktor pendorong tumbuhnya partisipasi masyarakat. Artinya, pembelajaran berbasis masalah merupakan strategi yang tepat untuk meningkatkan partisipasi masyarakat (Kementerian PUPR, 2016b; Ditjen Cipta Karya, 2017; Apriliana, 2018; Bathari, Limba \& Mustafa, 2018; dan Lamsi, 2019).

\section{KESIMPULAN 7}

Keberhasilan Program KOTAKU (Kota Tanpa Kumuh) di Kabupaten Bandung Barat, Jawa Barat, Indonesia merupakan upaya membangun masyarakat yang bertumpu pada pembangunan manusia, tidak hanya diukur dari keterlaksanaan program atau terselesaikannya masalah pemukiman kumuh, tapi diukur juga dari partisipasi masyarakat. Pembelajaran berbasis masalah merupakan strategi yang tepat untuk meningkatkan partisipasi masyarakat. Pembelajaran berbasis masalah telah berhasil meningkatkan partisipasi masyarakat, baik pada dimensi kontribusi, pengorganisasian, maupun dimensi pemberdayaan masyarakat.

Keberhasilan tersebut ditandai dengan banyaknya masyarakat yang berpartisipasi secara aktif dalam Program KOTAKU, seiring dengan terjadinya perubahan perilaku masyarakat berupa: berkembangnya keterampilan dalam memecahkan masalah; memaknai informasi; serta berpikir reflektif dan evaluatif, sehingga bisa menghemat biaya sampai dengan $30 \%$ dalam pelaksanaannya. ${ }^{8}$

${ }^{7}$ Sebuah Pengakuan: Ucapan terima kasih dan penghargaan yang tinggi disampaikan kepada: Kepala Dinas Cipta Karya Kabupaten Bandung Barat, Jawa Barat, Indonesia, yang telah memfasilitasi saya dalam melakukan penelitian mandiri ini. Kepada fasilitator yang telah membantu memberikan data yang dibutuhkan, juga saya ucapkan berbanyak terima kasih. Kepada para Pengurus LSM (Lembaga Swadaya Masyarakat) di Desa Padalarang, Desa Ciburuy, Desa Kertamulya, Desa Cimareme, Desa Mekar Sari, Desa Lembang, dan Desa Gudangkahuripan; serta semua Responden yang telah membantu sehingga penelitian saya dapat dilaksanakan sesuai rencana, sekali lagi, saya juga mengucapkan terima kasih dan penghargaan yang tinggi. Walau bagaimanapun, seluruh isi dan interpretasi dalam artikel ini - sebagai ringkasan dari Hasil Laporan Penelitian - tidak ada hubung-kaitnya dengan bantuan-bantuan yang telah mereka berikan; dengan perkataan lain, semuanya tetap menjadi tanggung jawab akademik saya sendiri secara pribadi.

${ }^{8}$ Pernyataan: Saya, dengan ini, menyatakan bahwa artikel ini adalah karya akademik saya sendiri, ianya bukan hasil plagiat, sebab sumber-sumber yang kata kutip dan rujuk terdapat secara jelas dalam daftar Referensi. Artikel ini juga belum pernah dikirim, direviu, dan diterbitkan oleh jurnal ilmiah lainnya. Saya bersedia mendapatkan sanksi 


\section{Referensi}

Apriliana, Sahria. (2018). "Partisipasi Masyarakat dalam Pelaksanaan Program Kota Tanpa Kumuh (KOTAKU): Studi tentang Program Pembangunan Drainase dan Sanitasi di Kelurahan Teritip, Kota Balikpapan" dalam e-Journal Administrasi Negara, Vol.6, No.1.

Arsyad, Lincolin. (2017). "Ekonomi Pembangunan dan Pembangunan Ekonomi”. Tersedia secara online di: http://www.pustaka.ut.ac.id/lib/wpcontent/uploads/pdfmk/ESPA4324-M1.pdf [diakses di Lembang, Jawa Barat, Indonesia: 2 Oktober 2018].

Arsil. (2019). "Implementasi Model Problem Based Learning Berbantuan Multimedia di Sekolah Dasar" dalam JGPD: Jurnal Gentala Pendidikan Dasar, Vol.4, No.1 [June], hlm.1-9.

Bathari, Andi Muhammad, Rekson Solo Limba \& La Ode Mustafa. (2018). "Implementation of the KOTAKU Program: Case Study in Kendari" in Journal of PUBLICUHO, organized and published by Faculty of Social and Political Sciences, Halu Oleo University in Kendari, Southeast Sulawesi, Indonesia. Available online also at: https://media.neliti.com/media/ publications/279517-implementation-of-thekotaku-program-cas-09cb6696.pdf [accessed in Lembang, West Java, Indonesia: March 11, 2019].

Christianingrum, S.I. \& T. Djumiarti. (2017). "Implementasi Program Kota Tanpa Kumuh di Kecamatan Semarang Timur”. Tersedia secara online di: https://ejournal3.undip.ac.id/index.php/ jppmr/article/viewFile/23515/21439 [diakses di Lembang, Jawa Barat, Indonesia: 2 Oktober 2018].

Ditjen [Direktorat Jenderal] Cipta Karya. (2017). "Bersama Program KOTAKU: Kita Tuntaskan Kumuh”. Kertas Kerja Tidak Diterbitkan. Tersedia dan dimiliki oleh Penulis.

Fitrianingsih, Indah Nur. (2018). "Model Pengembangan Masyarakat melalui Program KOTAKU (Kota Tanpa Kumuh): Studi Analisis di Desa Krajankulon, Kecamatan Kaliwungu, Kabupaten Kendal". Skripsi Sarjana Tidak Diterbitkan. Semarang: Fakultas Dakwah dan Komunikasi UIN [Universitas Islam Negeri] Walisongo. Tersedia secara online juga di: http:// eprints.walisongo.ac.id/8457/1/FULL\%20 SKRIPSI.pdf [diakses di Lembang, Jawa Barat, Indonesia: 1 Maret 2019].

Gunawan, Imam. (2013). Metode Penelitian Kualitatif: Teori dan Praktik. Jakarta: PT Bumi Aksara.

akademik, sekiranya apa-apa yang saya nyatakan ini, ternyata di kemudian hari, adalah tidak benar.
Hadi, Rio Anang \& Ema Umilia. (2018). "Bentuk Partisipasi Masyarakat dalam Program PLP-BK di Kelurahan Kedung Cowek" dalam Jurnal Teknik ITS, Vol.7, No.1, hlm.2337-3520.

"Hakikat Pembangunan Manusia: Definisi Human Development Index (HDI), Pengukuran Indeks Pembangunan Manusia, dan Permasalahan Terkini” dalam https://www.ajarekonomi.com/.../hakikatpembangunan-manusia-h [diakses di Lembang, Jawa Barat, Indonesia: 19 Februari 2019].

Hasan, Muhammad \& Muhammad Azis. (2018). Pembangunan Ekonomi \& Pemberdayaan Masyarakat: Strategi Pembangunan Manusia dalam Perspektif Ekonomi Lokal. Makassar: CV Nur Lina dan Taman Ilmu. Tersedia secara online juga di: http://eprints.unm.ac.id/10706/1/ Buku\%20pembangunan $\% 20$ ekonomi $\% 20$ contoh\%20fix.pdf [diakses di Lembang, Jawa Barat, Indonesia: 1 Maret 2019].

Ibrahim, M. \& M. Nur. (2000). Pengajaran Berdasarkan Masalah. Surabaya: UNESA [Universitas Negeri Surabaya] Press.

Indrawan, Rully \& Poppy Yaniawati. (2017). Metode Penelitian: Kuantitatif, Kualitatif, dan Campuran. Bandung: PT Refika Aditama.

Irvan, Hafidzita Eka Putri. (2017). "Partisipasi Masyarakat dalam Program Kota Tanpa Kumuh (KOTAKU) di Kelurahan Pesisir, Kecamatan Limapuluh, Kota Pekanbaru" dalam Jurnal JOM FISIP, Vol.5, No.1.

Kementerian PUPR [Pekerjaan Umum dan Perumahan Rakyat]. (2016a). Pedoman Umum Program Kota Tanpa Kumuh. Jakarta: Direktorat Jenderal Cipta Karya, Kementerian PUPR.

Kementerian PUPR [Pekerjaan Umum dan Perumahan Rakyat]. (2016b). Petunjuk Pelaksanaan Program KOTAKU Tingkat Desal Kelurahan. Jakarta: Direktorat Jenderal Cipta Karya, Kementerian PUPR.

Kurnia, Wijayanti, Sjamsiar Sjamsudin \& Mochamad Rozikin. (2010). "Upaya Badan Keswadayaan Masyarakat (BKM) dalam Pemberdayaan Masyarakat" dalam JAP: Jurnal Administrasi Publik, Vol.10, No.1.

Kusuma, A.R., S. Rande \& S. Apriliana. (2018). "Partisipasi Masyarakat dalam Program Kota Tanpa Kumuh (KOTAKU)" dalam e-Jurnal Administrasi Negara, Vol.6, No.1.

Lamsi, Shinta Arista. (2019). "Efektivitas Program Kota Tanpa Kumuh (Kotaku) dalam Peningkatan dan Pembangunan Infrastruktur: Studi pada Kelurahan Kangkung, Kecamatan Bumi Waras, Kota Bandar Lampung Tahun 2019”. Skripsi Sarjana Tidak Diterbitkan. Bandar Lampung: Jurusan Administrasi Negara FISIP UNILA [Fakultas Ilmu Sosial dan Ilmu Politik, 
Universitas Lampung]. Tersedia secara online juga di: http://digilib.unila.ac.id/59700/3/ SKRIPSI\%20TANPA\%20BAB \%20

PEMBAHASAN.pdf [diakses di Lembang, Jawa Barat, Indonesia: 24 Maret 2019].

"Laporan Pelaksanaan Program KOTAKU KBB (Kota Tanpa Kumuh Kabupaten Bandung Barat) Tahun 2018". Naskah Tidak Diterbitkan. Tersedia dan dimiliki oleh Penulis.

Madiasworo, Taufan. (2017). "Konsep Pencegahan Permukiman Kumuh". Makalah disampaikan dalam Lokakarya dan Pelatihan Pokja PKP Provinsi/Kabupaten/Kota untuk Program KOTAKU, di Jakarta, pada tanggal 10 Oktober.

Mardikanto, Totok. (2012). Pemberdayaan Masyarakat dalam Perspektif Kebijakan Publik. Bandung: Alfabeta.

Moeloeng, L.J. (1993). Metodologi Penelitian Kualitatif. Bandung: PT Remaja Rosyda Karya.

Mulyawan, Rahman. (2016). Masyarakat, Wilayah, dan Pembangunan. Bandung: UNPAD [Universitas Padjadjaran] Press. Tersedia secara online juga di: http://pustaka.unpad.ac.id/wpcontent/uploads/2016/10/04-Buku-OK_opt.pdf [diakses di Lembang, Jawa Barat, Indonesia: 9 Oktober 2018].

Mulyono, Agus. (2008). "Studi Partisipasi Masyarakat pada Program Desa Mandiri Pangan di Desa Muntuk, Kabupaten Bantul". Tesis Magister Tidak Diterbitkan. Semarang: PPs [Program Pascasarjana] Magister Teknik Pembangunan Wilayah dan Kota UNDIP [Universitas Diponegoro]. Tersedia secara online juga di: https://core.ac.uk/download/ pdf/11716172.pdf [diakses di Lembang, Jawa Barat, Indonesia: 9 Oktober 2018].

Nurhasanah. (2019). "Implementasi Kebijakan Program KOTAKU (Kota Tanpa Kumuh) dalam Upaya Meningkatkan Kesejahteraan Masyarakat" dalam JISoP: Jurnal Inovasi Ilmu Sosial dan Politik, Vol.1, No.1 [April], hlm.58-70.

Nursyahbani, Raisya \& Bitta Pigawati. (2015). "Kajian Karakteristik Kawasan Pemukiman Kumuh di Kampung Kota: Studi Kasus: Kampung Gandekan, Semarang" dalam Jurnal Teknik PWK, Vol.4, No.2. Tersedia secara online juga di: http://ejournal-s1.undip.ac.id/index.php/ pwk [diakses di Lembang, Jawa Barat, Indonesia: 17 Agustus 2018].

Nurzen, Yurizal et al. (2019). “Analisis Partisipasi Masyarakat dalam Program Neighborhood Upgrading and Shelter Project (NUSP) menuju Pembangunan Berkelanjutan di Wilayah Kumuh, Kelurahan Bram Itam Kiri, Kabupaten Tanjung Jabung Barat" dalam Jurnal Pembangunan Berkelanjutan, Vol.2, No.1. Tersedia secara online juga di: https://doi.org/10.22437/j pb.v21i1.5101 [diakses di Lembang, Jawa Barat, Indonesia: 18 Maret 2019].

"Padalarang: Antara Kemewahan dan Kawasan Paling Kumuh di Bandung Barat" dalam https:// www.pikiran-rakyat.combandung-raya-padalarangantara-kemewahan-dan-kawasan-paling-kumuh-dibandung-barat-428393 [diakses di Lembang, Jawa Barat, Indonesia: 18 Maret 2019].

"Pendekatan Partisipatif dalam Pemberdayaan Masyarakat" dalam http://digilib.uin-Suka. Ac.Id/8286/1/Aziz muslim [diakses di Lembang, Jawa Barat, Indonesia: 30 Maret 2019].

Rohimat, D., R. Rahmawati \& G.G. Seran. (2015). "Partisipasi Masyarakat dalam Implementasi Program KOTAKU/PNPM di Kecamatan Ciawi" dalam Jurnal Governasi, Vol.3, No.2.

Rukminto, Adi Isbandi. (2003). Intervensi Komunitas Pengembangan Masyarakat sebagai Upaya Pemberdayaan Masyarakat. Jakarta: Raja Grafindo Persada.

Rusman. (2011). Model-model Pembelajaran: Mengembangkan Profesionalisme Guru. Jakarta: PT Rajagrafindo Persada.

Sahroni. (2013). "Pengembangan Model Pemberdayaan Keluarga Miskin untuk Meningkatkan Kemandirian Sosial dan Ekonomi Keluarga di Pedesaan". Disertasi Doktor Tidak Diterbitkan. Bandung: SPs UPI [Sekolah Pascasarjana, Universitas Pendidikan Indonesia].

Siswoyo, Joko. (2017). “Overview Perubahan Paradigma KOTAKU” dalam Arsip Warta, pada 18 September. Tersedia secara online juga di: http://kotaku.pu.go.id:8081/wartaarsipdetil. asp? $\mathrm{mid}=8705 \&$ catid $=2 \&$ [diakses di Lembang, Jawa Barat, Indonesia: 2 Oktober 2018].

Sugiyono. (2009). Memahami Penelitian Kualitatif. Bandung: CV Alfa Beta.

"Surat Keputusan Bupati Bandung Barat, Nomor 663/Kep.447/Disperkim/2017 tentang Penetapan Wilayah Penerima Program Kota Tanpa Kumuh". Arsip Tidak Diterbitkan. Tersedia dan dimiliki oleh Penulis.

Sururi, Ahmad. (2015). "Pemberdayaan Masyarakat melalui Program Pembangunan Infrastruktur Perdesaan dalam Meningkatkan Kesejahteraan Masyarakat Kecamatan Wanasalam, Kabupaten Lebak" dalam Jurnal Administrasi Negara, Vol.3, No.2 [Januari-April], hlm.1-25.

Theresia, Aprilia. (2014). Pembangunan Berbasis Masyarakat. Bandung: Alfabeta.

Tsanita, Ayu. (2016). "Partisipasi Masyarakat di Perkotaan dalam Pelaksanaan Program Nasional Pemberdayaan Masyarakat (PNPM) Mandiri Perkotaan di Kota Bandar Lampung: Studi di Kelurahan Kaliawi, Kecamatan Tanjung Karang 
Pusat”. Skripsi Sarjana Tidak Diterbitkan.

Bandar Lampung: Jurusan Administrasi Negara FISIP UNILA [Fakultas Ilmu Sosial dan Ilmu Politik, Universitas Lampung]. Tersedia secara online juga di: http://digilib.unila.ac.id/23522/16/ SKRIPSI \%20TANPA \%20BAB $\% 20$

PEMBAHASAN.pdf [diakses di Lembang, Jawa Barat, Indonesia: 2 Oktober 2018].

Ulya, Afwah. (2018). "Partisipasi Masyarakat dalam Program Kota Tanpa Kumuh (KOTAKU) di Kelurahan Krobokan, Kecamatan Semarang Barat, Kota Semarang". Skripsi Sarjana Tidak Diterbitkan. Semarang: Fakultas Dakwah dan Komunikasi UIN [Universitas Islam Negeri] Walisongo. Tersedia secara online juga di: http:// eprints.walisongo.ac.id/9389/1/skripsi\%20full. pdf [diakses di Lembang, Jawa Barat, Indonesia: 1 Maret 2019].

Untari. (2017). "Menelisik Struktur Kota Kuno Mahenjo Daro vs Indikator Kumuh KOTAKU". Tersedia secara online di: http://kotaku.pu.go. id/view/3909/menelisik-struktur-kota-kunomahenjo-daro-vs-indikator-kumuh-kotaku/print [diakses di Lembang, Jawa Barat, Indonesia: 2 Oktober 2018].

"Waduh di Jabar Ada 2.848 Kawasan Pemukiman Kumuh" dalam https://finance.detik.com/.../ waduh-dijabarada-2848-kawasan-pemukimankumuh [diakses di Lembang, Jawa Barat, Indonesia: 18 Maret 2019].

Wawancara dengan Responden A, Kepala Dinas Cipta Karya di Kabupaten Bandung Barat, Jawa Barat, Indonesia, pada tanggal 3 Juli 2018.

Wawancara dengan Responden B, salah seorang Pengurus LSM (Lembaga Swadaya Masyarakat), di Desa Padalarang, Kabupaten Bandung Barat, Jawa Barat, Indonesia, pada tanggal 3 Juli 2018.

Wawancara dengan Responden C, salah seorang Pengurus LSM (Lembaga Swadaya Masyarakat), di Desa Ciburuy, Kabupaten Bandung Barat, Jawa Barat, Indonesia, pada tanggal 10 Juli 2018.

Wawancara dengan Responden D, salah seorang Pengurus LSM (Lembaga Swadaya Masyarakat), di Desa Kertamulya, Kabupaten Bandung Barat, Jawa Barat, Indonesia, pada tanggal 10 Juli 2018.

Wawancara dengan Responden E, salah seorang Pengurus LSM (Lembaga Swadaya Masyarakat), di Desa Cimareme, Kabupaten Bandung Barat, Jawa Barat, Indonesia, pada tanggal 17 Juli 2018.

Wawancara dengan Responden F, salah seorang Pengurus LSM (Lembaga Swadaya Masyarakat), di Desa Mekar Sari, Kabupaten Bandung Barat, Jawa Barat, Indonesia, pada tanggal 17 Juli 2018.

Wawancara dengan Responden G, salah seorang Pengurus LSM (Lembaga Swadaya Masyarakat), di Desa Lembang, Kabupaten Bandung Barat, Jawa Barat, Indonesia, pada tanggal 24 Juli 2018.

Wawancara dengan Responden $\mathrm{H}$, salah seorang Pengurus LSM (Lembaga Swadaya Masyarakat), di Desa Gudangkahuripan, Kabupaten Bandung Barat, Jawa Barat, Indonesia, pada tanggal 24 Juli 2018.

Yuniani, Sri, Gusty Putri \& Dhini Rosyida. (2017). "Kolaborasi dalam Perencanaan Program Kota Tanpa Kumuh (KOTAKU) di Kelurahan Semanggi, Kota Surabaya" dalam Jurnal Wacana Publik, Vo.1, No.2.

Zuharya, Almas. (2017). "Peranan Program Kota Tanpa Kumuh (KOTAKU) sebagai Media Pendidikan Sosial untuk Meningkatkan Keberdayaan Ekonomi: Studi Kasus pada Masyarakat Marginal di Desa Putih, Kecamatan Gampengrejo, Kabupaten Kediri”. Skripsi Sarjana Tidak Diterbitkan. Malang: Fakultas Tarbiyah dan Keguruan UIN [Universitas Islam Negeri] Maulana Malik Ibrahim. Tersedia secara online juga di: http://etheses.uin-malang. ac.id/9809/1/13130015.pdf [diakses di Lembang, Jawa Barat, Indonesia: 2 Oktober 2018]. 
SAHRONI,

Pembelajaran Masyarakat Berbasis Masalah

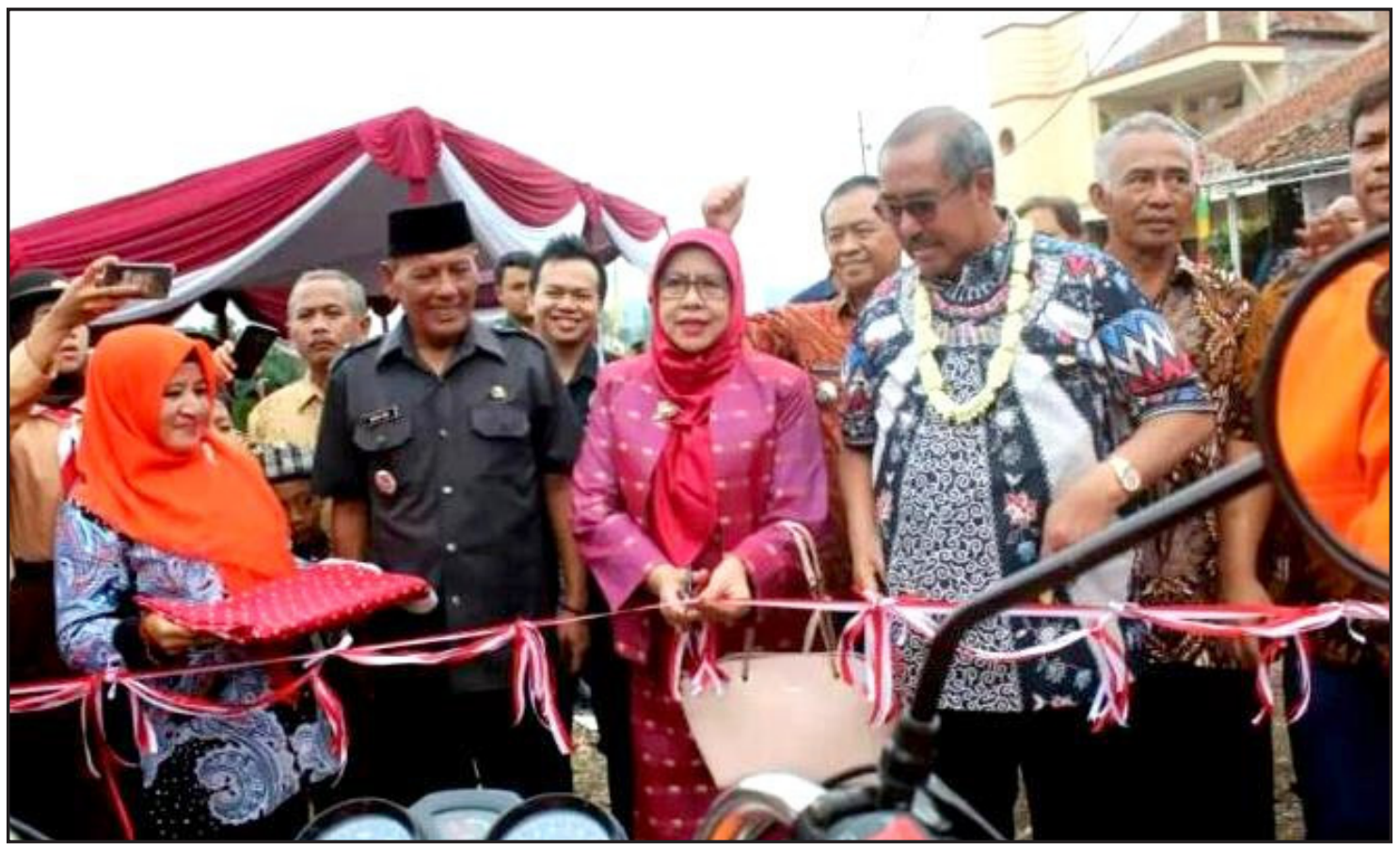

Program KOTAKU di Kabupaten Bandung Barat

(Sumber: http://jabarekspres.com/2017/bupati-luncurkan-program-kotaku, 9/10/2018)

Keberhasilan Program KOTAKU (Kota Tanpa Kumuh) di Kabupaten Bandung Barat, Jawa Barat, Indonesia merupakan upaya membangun masyarakat yang bertumpu pada pembangunan manusia, tidak hanya diukur dari keterlaksanaan program atau terselesaikannya masalah pemukiman kumuh, tapi diukur juga dari partisipasi masyarakat. Pembelajaran berbasis masalah merupakan strategi yang tepat untuk meningkatkan partisipasi masyarakat. Pembelajaran berbasis masalah telah berhasil meningkatkan partisipasi masyarakat, baik pada dimensi kontribusi, pengorganisasian, maupun dimensi pemberdayaan masyarakat. 